Published in final edited form as:

Nat Biotechnol. 2014 January ; 32(1): 76-83. doi:10.1038/nbt.2747.

\title{
Transient cytokine treatment induces acinar cell reprogramming and regenerates functional beta cell mass in diabetic mice
}

\author{
Luc Baeyens ${ }^{1,2}$, Marie Lemper ${ }^{1}$, Gunter Leuckx ${ }^{1}$, Sofie De Groef ${ }^{1}$, Paola Bonfanti ${ }^{1}$, Geert \\ Stangé ${ }^{1}$, Ruth Shemer ${ }^{3}$, Christoffer Nord ${ }^{4}$, David W. Scheel ${ }^{2}$, Fong C. Pan ${ }^{5}$, Ulf Ahlgren ${ }^{4}$, \\ Guoqiang $\mathrm{Gu}^{5}$, Doris A. Stoffers ${ }^{6}$, Yuval Dor ${ }^{3}$, Jorge Ferrer ${ }^{7}$, Gerard Gradwohl ${ }^{8}$, \\ Christopher VE Wright ${ }^{5}$, Mark Van de Casteele ${ }^{1}$, Michael S. German ${ }^{2}$, Luc Bouwens ${ }^{1,{ }^{*}}$, and \\ Harry Heimberg ${ }^{1, *}$ \\ ${ }^{1}$ Diabetes Research Center, Vrije Universiteit Brussel, 1090 Brussels, Belgium \\ ${ }^{2}$ Diabetes Center, California Institute for Regenerative Medicine (CIRM), University of California \\ San Francisco, San Francisco, CA 94143-0669, USA \\ ${ }^{3}$ The Institute for Medical Research Israel-Canada, The Hebrew University, Jerusalem, Israel \\ ${ }^{4}$ Umeå Center for Molecular Medicine, Umeå University, S-901 87 Umeå, Sweden \\ ${ }^{5}$ Vanderbilt University Program in Developmental Biology, Department of Cell and Developmental \\ Biology, Vanderbilt University Medical Center, Nashville, TN 37232, USA \\ ${ }^{6}$ Institute for Diabetes, Obesity, and Metabolism, University of Pennsylvania School of Medicine, \\ Philadelphia, PA 19104, USA \\ ${ }^{7}$ Institut d'Investigacions Biomediques August Pi i Sunyer, Hospital Clinic de Barcelona, \\ Barcelona, Spain and Imperial College London, London W12 0NN, United Kingdom \\ ${ }^{8}$ Development and Stem Cells Program, Institute of Genetics and Molecular and Cellular Biology \\ (IGBMC), Illkirch, 67404, France
}

\section{Abstract \\ Reprogramming of pancreatic exocrine cells into cells resembling beta cells may provide a strategy for treating diabetes. Here we show that transient administration of epidermal growth factor and ciliary neurotrophic factor to adult mice with chronic hyperglycemia efficiently stimulates the conversion of terminally differentiated acinar cells to beta-like cells. Newly generated beta-like cells are epigenetically reprogrammed, functional and glucose-responsive, and reinstate normal glycemic control for up to 248 days. The regenerative process depends on Stat 3 signaling and requires a threshold number of Neurogenin 3 (Ngn3) expressing acinar cells. In contrast to previous work demonstrating in vivo conversion of acinar cells to beta-like cells by}

Correspondence: Harry Heimberg, Diabetes Research Center, Vrije Universiteit Brussel, Laarbeeklaan 103, 1090 Brussels, Belgium. Tel: 32-2-477-4477; Fax: 32-2-477-4472; Harry.Heimberg@ vub.ac.be.

co-corresponding authors

AUTHOR CONTRIBUTIONS

Design: LBa, HH; Execution of experiments: LBa, ML, GL, SDG, RS, CN, DWS; Analyses: LBa, ML; Transgenic mouse strain generation: FCP, CVEW, YD, DAS, GG, JF, GG; Cell sorting: LBa, GS; Interpretation of results: LBa, ML, PB, UA, MSG, MvdC, HH; Writing: LBa, MSG, HH; Critical reading: LBa, PB, CVEW, YD, JF, GG, LBo, MvdC, MSG, HH; Project management: MSG, LBo, HH. 
viral delivery of exogenous transcription factors, our approach achieves acinar-to-beta cell reprogramming through transient cytokine exposure rather than genetic modification.

The potential to regenerate severely damaged tissue by converting one differentiated cell type to another is common in lower vertebrates ${ }^{1}$, but in mammals this conversion capacity is rare and mainly associated with pathological metaplasia ${ }^{2}$. Thus, the discovery of signaling pathways capable of inducing therapeutic cellular plasticity could open new avenues in regenerative medicine ${ }^{3,4}$. Insufficient functional beta cell mass, causes diabetes, a metabolic disorder with clinical complications arising from chronically elevated blood glucose levels. One potential treatment for this disease would be direct conversion of pancreatic non-beta cells into beta cells in sufficient numbers to restore and maintain normoglycemia. The capacity of other adult pancreatic cell types to give rise to new beta cells remains unclear. Genetic lineage tracing in mice demonstrated that under conditions of normal physiology or modest beta cell damage, pre-existing beta cells are solely responsible for generation of new beta cells by self-duplication ${ }^{5,6}$. But with extensive tissue damage by surgical duct ligation, facultative progenitor cells located near the lining of exocrine duct structures are activated to differentiate into new beta cells ${ }^{7}$. Nevertheless, a duct-related origin of these progenitor cells was contradicted by recent reports using genetic lineage tracing with different duct-specific promoters $^{8-12}$. Other work showed that following toxin-induced ablation of the near-total beta cell mass alpha cells are reprogrammed to new beta cells ${ }^{13}$.

The possibility of converting acinar cells to beta cells was suggested in a study in which diabetic mice were treated with epidermal growth factor (EGF) and gastrin ${ }^{14}$. However, this study lacked evidence by genetic lineage tracing, and subsequent genetic lineage tracing in mice did not support an acinar cell origin of beta cells in several regenerative settings in the injured adult pancreas ${ }^{15}$. In a notable advance, transduction of mouse acinar cells in vivo with vectors encoding three transcription factors that are necessary for beta cell development induced direct conversion of acinar cells to functional beta-like cells ${ }^{16}$. Further supporting the notion of lineage plasticity of acinar cells, rodent acinar cells can adopt a duct-like phenotype following suspension culture ${ }^{17-19}$, dexamethasone treatment can induce their transdifferentiation to a hepatocyte-like cell ${ }^{20}$ and addition of epidermal growth factor (EGF) in combination with nicotinamide, leukemia inhibitory factor (LIF) or ciliary neurotrophic factor (CNTF) can stimulate their reprogramming into insulin-positive cells ${ }^{21-24}$ and own unpublished data. However, the capacity to reprogram acinar cells to beta cells in vivo without genetic manipulation has not been demonstrated.

Given that EGF in combination with either LIF or CNTF can reprogram rat acinar cells into insulin-producing beta-like cells in vitro ${ }^{21-23}$, we tested the capacity of EGF and CNTF to induce beta cell regeneration in diabetic mice. We show that this therapy regenerates a functional beta cell mass sufficient to normalize hyperglycemia and maintain normoglycemia for at least 248 days. The regenerative process involves reprogramming of acinar cells and depends on activation of the pro-endocrine regulator gene $\mathrm{Ngn3}$ and signaling through STAT3. These results and this experimental model may aid future studies of the potential for using pharmacologic manipulation of signaling pathways as a therapy for diabetes. 


\section{RESULTS}

\section{EGF and CNTF restore normoglycemia}

We administered EGF and CNTF treatment to 13 week-old mice that had been hyperglycemic for 5 weeks. Hyperglycemia was induced by intravenous (i.v.) injection of a single dose of the beta-cell toxin alloxan $(\mathrm{ALX})^{25}$. All ALX-treated mice $(\mathrm{n}=70)$ displayed a sharp increase in blood sugar concentrations and these concentrations remained above 25 $\mathrm{mmol} / \mathrm{L}$ (Figure 1A). Five weeks after ALX injection, mini-osmotic pumps were implanted into the peritoneum to deliver either EGF and CNTF or vehicle. At the time of pump implantation the average glycemia was $32.8 \pm 2.7 \mathrm{mmol} / \mathrm{L}$ in ALX-treated mice $(\mathrm{n}=70$; referred to as $\mathrm{ALX}_{35 \mathrm{~d}}$ ) compared to $5.4 \pm 0.4 \mathrm{mmol} / \mathrm{L}$ in control mice with normoglycemia $\left(\mathrm{NG}_{35 \mathrm{~d}}\right)(\mathrm{n}=10 ; \mathrm{p}<0.01)$. These pumps release their contents at a constant flux rate over a 7 days period. Of all $\mathrm{ALX}_{35 \mathrm{~d}}$ mice implanted with cytokine-releasing pumps ( $\mathrm{n}=35$; referred to as $\left.\mathrm{ALX}_{35 \mathrm{~d} / \mathrm{CK}}\right) 64.7 \pm 2.1 \%$ responded to the cytokine mix and showed glycemia lower than $14 \mathrm{mmol} / \mathrm{L}$; these responsive mice henceforth are referred to as $\mathrm{ALX}_{35 \mathrm{~d} / \mathrm{CK}^{\text {resp }} \text {. In }}$ contrast, cytokine-unresponsive mice (referred to as $\mathrm{ALX}_{35 \mathrm{~d} / \mathrm{CK}^{\text {unresp }}}$ ) remained hyperglycemic, as did $\mathrm{ALX}_{35 \mathrm{~d}}$ mice implanted with control pumps (referred to as $\left.\mathrm{ALX}_{35 \mathrm{~d} / \mathrm{CTR}}\right)$. The cytokine combination did not affect the blood sugar levels of normoglycemic mice (Figure 1A). ALX $35 \mathrm{~d} / \mathrm{CK}^{\text {resp }}$ mice were, on average, more glucose tolerant than $\mathrm{ALX}_{35 \mathrm{~d} / \mathrm{CTR}}$ mice (Figure 1B) but their blood glucose remained higher than that in $\mathrm{NG}_{35 \mathrm{~d} / \mathrm{CTR}}$ mice. All animals were insulin sensitive, but $\mathrm{ALX}_{35 \mathrm{~d} / \mathrm{CK}}{ }^{\text {resp }}$ mice were more sensitive than $\mathrm{NG}_{35 \mathrm{~d} / \mathrm{CTR}}$ mice (Figure 1C).

The body weights of both $\mathrm{ALX}_{35 \mathrm{~d} / \mathrm{CK}}$ and $\mathrm{ALX}_{35 \mathrm{~d} / \mathrm{CTR}}$ mice were lower than those of $\mathrm{NG}_{35 \mathrm{~d} / \mathrm{CK}}$ and $\mathrm{NG}_{35 \mathrm{~d} / \mathrm{CTR}}$ mice but the difference became statistically significant only after pump implantation $(\mathrm{p}<0.05$ ) (Figure 1D). ALX $35 \mathrm{~d} / \mathrm{CTR}$ mice remained severely hyperglycemic and eventually died, whereas normoglycemia persisted for at least 248 days beyond CK release in $\mathrm{ALX}_{35 \mathrm{~d} / \mathrm{CK}^{\text {resp }}}$ mice (Supplementary Fig. 1A online) and during this time the gain of body weight by these responsive mice was parallel to that in NG control mice (Supplementary Fig. 1B online)., At the end of the 7 days CK release, ALX $_{35 d}$ mice showed lower fat and lean mass than $\mathrm{NG}_{35 \mathrm{~d}}$ mice (Supplementary Fig. $1 \mathrm{C}$ online).

Pancreas insulin content (Figure 1F) and serum insulin levels (both in fasted and glucosestimulated animals) (Figure 1G) were significantly increased in ALX $_{35 \mathrm{~d} / \mathrm{CK}}$ compared with ALX $_{35 \mathrm{~d} / \mathrm{CTR}}$ mice, but still lower than in $\mathrm{NG}_{35 \mathrm{~d} / \mathrm{CTR}}$ mice. Serum glucagon levels were similar in all groups of mice (Supplementary Fig. 1D online). Importantly, islets isolated from $\mathrm{NG}_{35 \mathrm{~d} / \mathrm{CTR}}$ and $\mathrm{ALX}_{35 \mathrm{~d} / \mathrm{CK}}$ mice, secreted similar amounts of insulin after glucosestimulation (Figure 1H).

Notably, treatment with either EGF or CNTF alone did not induce normoglycemia (Supplementary Fig. 1E,F online). However, the combination of EGF and CNTF also improved glycemia and body weight in a second model of diabetes in which beta cell destruction was induced by streptozotocin (STZ), be it at a 50\% lower efficiency than following ALX (33.3 $\pm 1.5 \%$ of $\mathrm{STZ}_{35 \mathrm{~d} / \mathrm{CK}}$ mice showed markedly decreased glycemia by day 7 of treatment $(n=15)$ and glycemia remained stable in the responsive mice for at least 72 days). The effect of cytokine treatment is thus less impressive in STZ-treated mice, 
possibly because of they showed slightly lower glycemia than ALX-treated mice prior to pump implantation (Supplementary Fig. 1G,H online).

After ALX-mediated beta cell destruction, the fraction of insulin ${ }^{+}$cells in tissue sections of pancreas from $\mathrm{ALX}_{35 \mathrm{~d} / \mathrm{CTR}}$ and $\mathrm{ALX}_{35 \mathrm{~d} / \mathrm{CK}}{ }^{\text {unresp }}$ mice remained similar ( $\left.>0.05 ; \mathrm{n}=6\right)$, but $\mathrm{ALX}_{35 \mathrm{~d} / \mathrm{CK}^{\text {resp }}}$ mice showed a significant increase starting on day 39 (4 days after pump implantation) $(\mathrm{p}<0.05 ; \mathrm{n}=6)$ albeit not to the same level observed in $\mathrm{NG}_{35 \mathrm{~d} / \mathrm{CTR}}$ mice $(\mathrm{p}<0.01 ; \mathrm{n}=6)$ (Figure 1I). We also measured insulin ${ }^{+}$cell mass by morphometry at various time points after ALX injection. The ratio of insulin ${ }^{+}$area to the total area of the pancreas tissue section was highest in $\mathrm{NG}_{\mathrm{CTR}}$ mice at all time points and significantly increased in $\mathrm{ALX}_{35 \mathrm{~d} / \mathrm{CK}^{\text {resp }}}$ mice starting on day 42 (Supplementary Fig. 1I online).

We observed actively cycling beta cells at various time points following ALX treatment. The fraction of insulin ${ }^{+}$cells that expressed Ki67 was highest in $\mathrm{NG}_{35 \mathrm{~d} / \mathrm{CTR}}$ mice at all time points ( $\mathrm{p}<0.01 ; \mathrm{n}=6)$, remained equally low in $\mathrm{ALX}_{35 \mathrm{~d} / \mathrm{CTR}}$ and $\mathrm{ALX}_{35 \mathrm{~d} / \mathrm{CK}}{ }^{\text {unresp }}$ mice ( $p>0.05 ; n=6)$ and increased to a statistically significant extent in $\mathrm{ALX}_{35 \mathrm{~d} / \mathrm{CK}}{ }^{\text {resp }}$ mice starting at day $42(\mathrm{p}<0.05 ; \mathrm{n}=6)$ (Supplementary Fig. 1JK online). In contrast, cumulative DNA synthesis by beta cells, measured as the fraction of $\mathrm{IdU}^{+}$insulin ${ }^{+}$cells, was highest in $\operatorname{ALX}_{35 \mathrm{~d} / \mathrm{CK}}{ }^{\text {resp }}$ mice $(\mathrm{p}<0.05 ; \mathrm{n}=4)$ (Supplementary Fig. $1 \mathrm{~L}, \mathrm{M}$ online). These data provide evidence of a modest increase in beta cell replication in $\mathrm{ALX}_{35 \mathrm{~d} / \mathrm{CK}}{ }^{\text {resp }}$ mice, especially towards the end of cytokine-treatment and justified a search for the origin of the newly formed beta-like cells by lineage tracing.

\section{Acinar cell origin of beta-like cells}

To elucidate the origin of the newly formed insulin-expressing cells in $\mathrm{ALX}_{35 \mathrm{~d} / \mathrm{CK}}$ mice, we used genetic lineage tracing; more specifically, we tracked insulin-expressing beta cells, elastase-expressing acinar cells and HNF1b-expressing duct cells. For example, we used Rip $^{\text {CreERT }}{ }^{2} 26^{\text {LacZ }}$ mice ${ }^{5}$ that following tamoxifen (TAM) injection activate Cre expression that, in turn, induces expression of LacZ, which encodes $\beta$-galactosidase. As such, cells that exhibited insulin promoter activity at some point during their existence can be marked by $\mathrm{XGal}$ staining which detects $\beta$-galactosidase. In these experiments, tracer mice were injected with TAM followed by a 24 day period of TAM washout, followed by a 35 day period of hyperglycemia (Figure $2 \mathrm{~A}$ ). The majority of $\mathrm{Pdx}^{+}$beta cells in $\mathrm{NG}_{35 \mathrm{~d} / \mathrm{CTR}}$ and $\mathrm{ALX}_{35 \mathrm{~d} / \mathrm{CTR}}$ Rip $^{\text {CreERT }}$ 26 ${ }^{\mathrm{LacZ}}$ mice mice showed Xgal-reactivity $(81.5 \pm 2.5 \%$; $\mathrm{n}=12$, and $84.3 \pm 3.8 \%$; $\mathrm{n}=12$, respectively) (Figure $2 \mathrm{~B}, \mathrm{C}$ ). We stained for Pdx 1 rather than insulin to avoid omitting beta cells that had degranulated during hyperglycemia. However, in $\mathrm{ALX}_{35 \mathrm{~d} / \mathrm{CK}}$ mice only $7.2 \pm 0.9 \%(n=12 ; \mathrm{p}<0.01)$ of the Pdx $1^{+}$cells were Xgal-reactive. These data indicate that the population of beta cells that were labeled prior to CK-treatment was strongly diluted following treatment, suggesting that new beta-like cells originated from non-beta cells.

The possible contribution of duct cells to newly formed insulin ${ }^{+}$cells was determined in Hnf $1 b^{\text {CreERT }}$ 26 $^{\text {LacZ }}$ tracer mice in which the HNF1b promoter is specifically expressed in duct cells ${ }^{8}$. In both $\mathrm{ALX}_{35 \mathrm{~d} / \mathrm{CTR}}$ and $\mathrm{ALX}_{35 \mathrm{~d} / \mathrm{CK}}$ mice $19 \%$ of all duct cells expressed the reporter (Supplementary Fig. 2A,B online). In $\mathrm{ALX}_{35 \mathrm{~d} / \mathrm{CK}}$ mice $1.1 \pm 0.5 \%$ of beta-like cells were stained by $\mathrm{Xgal}^{+}$, a small but significantly higher fraction than the $0.4 \pm 0.4 \% \mathrm{Xgal}^{+}$ beta cells found in $\mathrm{ALX}_{35 \mathrm{~d} / \mathrm{CTR}}$ mice ( $\mathrm{n}=12$ in each experimental group, $\left.\mathrm{p}<0.05\right)$. These 
results therefore suggest that the number of beta-like cells derived from duct cells in $\mathrm{ALX}_{35 \mathrm{~d} / \mathrm{CK}}$ mice was too low to account for the observed total increase in beta-like cells.

Acinar cells were labeled in Ela ${ }^{\mathrm{CreERT}} \mathrm{R} 26^{\mathrm{LacZ}}$ mice $^{19}$ (Ela denotes elastase, a marker of acinar cells) with a recombination efficiency of $45 \%$ in $\mathrm{ALX}_{35 \mathrm{~d} / \mathrm{CTR}}$ and $\mathrm{ALX}_{35 \mathrm{~d} / \mathrm{CK}}$ mice (Figure 2E). In $\mathrm{ALX}_{35 \mathrm{~d} / \mathrm{CK}} \mathrm{Ela}^{\mathrm{CreERT}} \mathrm{R} 26^{\mathrm{LacZ}}$ mice, $32.1 \pm 2.1 \%$ of insulin ${ }^{+}$cells were $\mathrm{Xgal}^{+}$ (Figure 2D,E), whereas only $1.0 \pm 0.5 \%$ of insulin ${ }^{+}$cells were $\mathrm{Xgal}^{+}$in $\mathrm{ALX}_{35 \mathrm{~d} / \mathrm{CTR}}$ mice $(\mathrm{n}=13 ; \mathrm{p}<0.01)$. Of the total number of $\mathrm{Xgal}^{+}$cells, $0.02 \pm 0.01 \%$ were insulin ${ }^{+}$in $\operatorname{ALX}_{35 \mathrm{~d} / \mathrm{CTR}}$ mice and 3.0 $\pm 0.4 \%$ were insulin ${ }^{+}$in $\operatorname{ALX}_{35 \mathrm{~d} / \mathrm{CK}}$ mice $(\mathrm{n}=13 ; \mathrm{p}<0.01)$. These findings were confirmed using Ptf $1 \mathrm{a}^{\mathrm{CreERT}} \mathrm{R} 26^{\mathrm{YFP}}$ mice as an alternative approach for lineage tracing acinar cell-derived descendants ${ }^{26}$ (Supplementary Fig. 3A online); these mice showed an overall recombination efficiency of $50 \%$ of acinar cells in all experimental groups (Supplementary Fig. 3B online). Four days after pump implantation, pancreases of Ptf1a ${ }^{\text {CreERT }}$ R26 ${ }^{\text {YFP }}$ mice contained small clusters of $3.4 \pm 0.6$ insulin ${ }^{+}$cells dispersed within the parenchyma, many of which were $\mathrm{YFP}^{+}$and thus derived from acinar cells (Supplementary Fig. 3C online). The average number of beta-like cells per cluster was significantly increased at day 7 after pump implantation (35.2 \pm 4.6 insulin $^{+}$cells/cluster; $\mathrm{n}=25 ; \mathrm{p}<0.01)$ but was significantly lower than in $\mathrm{NG}_{35 \mathrm{~d} / \mathrm{CTR}}$ mice $(69.8 \pm 7.0$ cells/cluster $)$. At this time point, YFP was expressed in $43.1 \pm 3.5 \%$ of insulin ${ }^{+}$cells of Ptf $1 \mathrm{a}^{\mathrm{CreERT}}{ }_{\mathrm{R} 26}{ }^{\mathrm{YFP}}$ $\operatorname{ALX}_{35 \mathrm{~d} / \mathrm{CK}}$ mice $(\mathrm{n}=12)$, compared with $1.0 \pm 0.7 \%$ of insulin ${ }^{+}$cells in $\mathrm{ALX}_{35 \mathrm{~d} / \mathrm{CTR}}$ mice $(\mathrm{n}=12 ; \mathrm{p}<0.001)$. In $\mathrm{NG}_{35 \mathrm{~d} / \mathrm{CTR}}$ animals, only $0.2 \pm 0.1 \%$ of insulin ${ }^{+}$cells co-expressed YFP (Supplementary Fig. 3B online). These results indicate that the majority of newly formed beta-like cells in $\mathrm{ALX}_{35 \mathrm{~d} / \mathrm{CK}}$ mice originated from elastase ${ }^{+} \mathrm{Ptfla}^{+}$acinar cells.

To compare the DNA methylation at the beta-cell-specific insulin and GLUT2 promoters and the acinar cell-specific Amy2b promoter in new beta-like cells derived from acinar cells and those in normal beta-cells and acinar cells, we sorted these three cell populations from Ptf1a ${ }^{\text {CreERT }}{ }_{\text {R26 }}{ }^{\text {YFP }}$ NG $_{35 \mathrm{~d} / \mathrm{CTR}}$ and ALX $35 \mathrm{~d} / \mathrm{CK}$ mice by flow cytometry (Supplementary Fig. 3D online). Insulin and GLUT2 promoter DNA was hypomethylated at CpG sequences in normal beta cells and acinar cell-derived beta-like cells, whereas acinar cells displayed marked hypermethylation on these beta cell-specific promoters. The acinar cell-specific Amy 2 b promoter was hypomethylated in acinar cells but strongly methylated in acinar cellderived beta-like cells (Supplementary Fig. 3E online).

\section{Ngn3 in acinar-to-beta reprogramming}

Cytokine-induced reprogramming of rat acinar cells into beta-like cells requires reexpression of Neurogenin-3 (Ngn3) ${ }^{22}$, a bHLH transcription factor required for islet cell formation during embryonic development. Therefore, we examined Ngn3 expression in the pancreas of cytokine-treated diabetic mice. We detected an increase in Ngn3 expression in $\mathrm{ALX}_{35 \mathrm{~d} / \mathrm{CK}}$ compared with $\mathrm{ALX}_{35 \mathrm{~d} / \mathrm{CTR}}$ and $\mathrm{NG}_{35 \mathrm{~d} / \mathrm{CTR}}$ mice (Supplementary Fig. 4A online). Next we used Ngn3 ${ }^{\text {YFP }}$ (knock-add-on) mice, in which YFP is inserted in the $3^{\prime}$ untranslated region of the $N g n 3$ locus ${ }^{27}$, to identify $\mathrm{YFP}^{+}$cells on pancreas sections. $\mathrm{YFP}^{+}$ cells were dispersed over the exocrine and endocrine compartments of the pancreas in $\mathrm{ALX}_{35 \mathrm{~d} / \mathrm{CK}}$ but not $\mathrm{ALX}_{35 \mathrm{~d} / \mathrm{CTR}}$ mice (Figure $3 \mathrm{~A}-\mathrm{C}$ ). The majority of the $\mathrm{YFP}^{+}$cells coexpressed amylase, $\left(176 \pm 31\right.$ amylase ${ }^{+} \mathrm{YFP}^{+}$cells per $10^{5}$ pancreas cells counted, 
representing $84.5 \pm 7.8 \%$ of all $\mathrm{YFP}^{+}$cells $)$and some expressed insulin $\left(10 \pm 2 \mathrm{Insulin}^{+} \mathrm{YFP}^{+}\right.$ cells per $10^{5}$ pancreas cells counted, representing $9.2 \pm 1.7 \%$ of all $\mathrm{YFP}^{+}$cells; $\mathrm{n}=15$ ). $1.6 \pm 0.3 \%(n=15)$ of acinar cells expressed YFP (Figure 3B), and $5.1 \pm 0.6 \%(n=15)$ of betacells expressed YFP (Figure 3C). Of all $\mathrm{YFP}^{+}$cells $27.1 \pm 2.8 \%$ still expressed the Ngn3 protein and all $\mathrm{YFP}^{+}$cells showed a strong immune reactivity for Pdx1, regardless of their location (Figure 3D). These observations are consistent with a model in which $\mathrm{Ngn}^{+}$cells appear within the exocrine parenchyma of $\mathrm{ALX}_{35 \mathrm{~d} / \mathrm{CK}}$ mice, cluster together and eventually lose YFP expression as insulin protein becomes detectable.

Next we isolated undifferentiated potential progenitors of beta cells from $\mathrm{Ngn}^{\mathrm{YFP}}$ mice by flow cytometric sorting of cells that express YFP (Figure 3E. From the pancreas of $\mathrm{ALX}_{35 \mathrm{~d} / \mathrm{CK}^{\text {resp }}}$ mice 14,322 $\pm 1,235 \mathrm{YFP}^{+}$cells were isolated (Figure 3F), Only 1,968 \pm 243 $\mathrm{YFP}^{+}$cells were isolated from $\mathrm{ALX}_{35 \mathrm{~d} / \mathrm{CK}}$ unresp mice and $178 \pm 19$ from $\mathrm{NG}_{35 \mathrm{~d} / \mathrm{CTR}}$ mice $(n=15 ; p<0.01)$ (Figure 3F). Although based on correlation, these findings suggest that the number of $\mathrm{Ngn}^{+}$cells may determine the threshold for a successful regenerative process.

From pancreas of $\mathrm{ALX}_{35 \mathrm{~d} / \mathrm{CK}}$ mice $46,587 \pm 417 \mathrm{YFP}^{-} \mathrm{SSC}^{\text {high }} \mathrm{TSQ}^{+}$cells (that show high sideward scatter (SSChigh) and stain with 6-Methoxy-8-p-toluenesulphonamido-quinoline (TSQ), a zinc-chelating near-UV fluorophore that labels granulated beta cells ${ }^{7}$ ) were isolated as compared to $694 \pm 143$ from $\operatorname{ALX}_{35 \mathrm{~d} / \mathrm{CTR}}$ (Figure $3 \mathrm{G}$ ) and 94,261 \pm 566 from $\mathrm{NG}_{35 \mathrm{~d} / \mathrm{CTR}}$ mice. Of $\mathrm{YFP}^{+} \mathrm{SSC}^{\text {low TSQ }}{ }^{-}$cells sorted from $\mathrm{ALX}_{35 \mathrm{~d} / \mathrm{CKresp}}$ mice, $87 \%$ stained positive for YFP (using a YFP-specific antibody), 23\% stained positive for Ngn3 and only $3 \%$ stained positive for insulin (Figure $3 \mathrm{H}$ ). $\mathrm{YFP}^{-} \mathrm{SSC}^{\text {high }} \mathrm{TSQ}^{+}$cells from $\mathrm{ALX}_{35 \mathrm{~d} / \mathrm{CKresp}}$ mice were $61 \%$ insulin $^{+}$and as expected represent the granulated differentiated endocrine cell pool (Figure 3H). Transcripts encoding the transcription factors Ngn3, Pax4 and Sox9, characteristic of progenitor cells in embryonic endocrine pancreas, were detected in $\mathrm{YFP}^{+} \mathrm{SSC}^{\text {low }} \mathrm{TSQ}^{-}$cells but neither in $\mathrm{YFP}^{+} \mathrm{SSC}^{\text {high }} \mathrm{TSQ}^{+}$cells nor in $\mathrm{YFP}^{-} \mathrm{SSC}^{\text {high }} \mathrm{TSQ}^{+}$ beta cells. Pdx1 and NeuroD1 mRNA was in all three conditions and strong Insulin 1 expression was only present in $\mathrm{YFP}^{+} \mathrm{SSC}^{\text {high }} \mathrm{TSQ}^{+}$cells and in $\mathrm{YFP}^{-} \mathrm{SSC}^{\text {high }} \mathrm{TSQ}^{+}$cells. This observation supports a low degree of differentiation of the first and a more differentiated state of the latter two cell fractions (Supplementary Fig. 4B online). As such, the elevated number of $\mathrm{YFP}^{-} \mathrm{SSC}^{\text {high }} \mathrm{TSQ}^{+}$differentiated cells in $\mathrm{ALX}_{35 \mathrm{~d} / \mathrm{CK}}$ mice is consistent with their lowered blood glucose level, improved glucose tolerance and increased number of beta-like cells.

We next used genetic lineage tracing to assess whether newly formed insulin ${ }^{+}$cells previously expressed $\mathrm{Ngn} 3$. Specifically, the $\mathrm{Ngn} 3^{+}$cell lineage was permanently traced in $\mathrm{Ngn} 3^{\mathrm{CreERT}} \mathrm{R} 26^{\mathrm{YFP}}$ mice that were injected with TAM 5 times around the day of pump implantation. YFP expression was subsequently examined to identify cells that originated from $\mathrm{Ngn}^{+}$cells during the cytokine treatment (Figure 4A). YFP was present in a small percentage of insulin ${ }^{+}$or amylase ${ }^{+}$cells in $\mathrm{ALX}_{35 \mathrm{~d} / \mathrm{CTR}}, \mathrm{NG}_{35 \mathrm{~d} / \mathrm{CTR}}$ and $\mathrm{ALX}_{35 \mathrm{~d} / \mathrm{CK}}$ unresp mice (Figure $4 \mathrm{~B}, \mathrm{C})$. In contrast, $\mathrm{ALX}_{35 \mathrm{~d} / \mathrm{CK}^{\text {resp }}}$ pancreases (10 independent mice analyzed) contained 2.8 \pm 0.4 clusters of amylase+ $\mathrm{YFP}^{+}$insulin ${ }^{-}$cells per section, and $89.8 \pm 1.4 \%$ of insulin ${ }^{+}$cells were $\mathrm{YFP}^{+}$(Figure 4B,C). Notably, few alpha cells expressed YFP, suggesting that $\mathrm{Ngn}^{+}$cells only marginally contributed to the alpha cell population $(<3 \%$ in all conditions tested) (Figure S5A-B). Together with the acinar cell lineage tracing, these 
results indicate that most beta-like cells in EGF and CNTF-treated diabetic mice derived from Ngn3-expressing acinar cells.

To examine whether acinar to beta-like cell conversion in $\mathrm{ALX}_{35 \mathrm{~d} / \mathrm{CK}}$ mice requires Ngn3, we inactivated the Ngn3 gene in acinar cells of Ptf1 $\mathrm{a}^{\mathrm{CreERT}} \mathrm{R} 26^{\mathrm{YFP}} \mathrm{Ngn} 3^{\text {lox/lox }}$ mice by TAM treatment before injection of ALX. As expected, TAM treatment induced YFP labeling (indicating Cre-mediated recombination) in $~ 50 \%$ of acinar cells in all mice regardless of ALX and pump treatment (Supplementary Fig. 6A,D online). In ALX $35 \mathrm{~d} / \mathrm{CK}$ mice the number of $\mathrm{YFP}^{+}$beta-like cells was markedly decreased in animals that deleted two Ngn3 alleles ( $p<0.01)$ (Supplementary Fig. 6B online). Furthermore, the total number of beta-like cells (both $\mathrm{YFP}^{+}$and $\mathrm{YFP}^{-}$) in the pancreases of TAM-treated $\mathrm{ALX}_{35 \mathrm{~d} / \mathrm{CK}}$ Ptf1 ${ }^{\mathrm{CreERT}}{ }_{\mathrm{R}} 26^{\mathrm{YFP}} \mathrm{Ngn} 3^{\text {lox/lox }}$ mice was reduced by approximately half $(\mathrm{p}<0.01)$ (Supplementary Fig. 6C,D online). Because R26 ${ }^{\mathrm{YFP}}$ and $\mathrm{Ngn} 3^{\text {lox/lox }}$ recombination occurs in the same acinar cells, the $50 \%$ recombination efficiency of Ptf $1 \mathrm{a}^{\mathrm{CreERT}}$ mice (Supplementary Fig. 6A online) in combination with the 94\% reduction in beta-like cell reprogramming of recombined acinar cells lacking Ngn3 (Supplementary Fig. 6B online) explains the magnitude of the reduction in total beta-like cells (Supplementary Fig. 6C,D online). In accordance with these findings, blood glucose levels in $\mathrm{ALX}_{35 \mathrm{~d} / \mathrm{CK}}$ mice with acinar-specific loss of Ngn3 were significantly higher than those in $\mathrm{ALX}_{35 \mathrm{~d} / \mathrm{CK}}$ mice $(\mathrm{n}=4$; $\mathrm{p}<0.05$ ) (Supplementary Fig. 6E online). Taken together, these results demonstrate that acinar-to-beta reprogramming in this model requires the pro-endocrine regulator Ngn3.

\section{STAT3 in acinar-to-beta reprogramming}

To identify the pancreatic cell types that can act as primary targets of CNTF in ALX $_{35 \mathrm{~d} / \mathrm{CK}}$ mice, we measured CNTF signaling by analyzing phosphorylation of Stat3. In pancreases of $\mathrm{ALX}_{35 \mathrm{~d} / \mathrm{CK}}{ }^{\text {resp }}$ mice, activated Stat3 (phospho-Stat3) was detected in the nuclei of $53.2 \pm 7.8 \%$ of extra-islet (mainly acinar) and $76.6 \pm 4.9 \%$ of islet cells $(n=10)$ (Figure 5A). The level of phospho-Stat3 staining was highest in the islet cells. In contrast, activated Stat3 was absent from the pancreas of $\mathrm{NG}_{35 \mathrm{~d} / \mathrm{CTR}}, \mathrm{ALX}_{35 \mathrm{~d} / \mathrm{CTR}}$ and $\mathrm{ALX}_{35 \mathrm{~d} / \mathrm{CK}}{ }^{\text {unresp }}$ mice $(\mathrm{n}=10)$ (Figure 5A). Using Ptf1a ${ }^{\text {CreERT }}$ R26 ${ }^{\text {YFP }}$ mice we demonstrated expression of phospho-Stat3 in both acinar cells and newly formed beta-like cells (Figure 5B).

Excision of the Stat3 gene in pre-existing acinar cells of Ptf $1 \mathrm{a}^{\mathrm{CreERT}} \mathrm{R} 26^{\mathrm{YFP}} \mathrm{Stat} 3^{\text {lox/lox }}$ mice by TAM-treatment before injection of ALX, prevented the normalization of hyperglycemia in $\mathrm{ALX}_{35 \mathrm{~d} / \mathrm{CK}}$ mice (Figure 5C), suggesting a requirement for CNTF signaling directly in acinar cells. Moreover, in $\mathrm{ALX}_{35 \mathrm{~d} / \mathrm{CK}}$ mice with an acinar-specific excision of Stat3, the number of YFP+insulin ${ }^{+}$cells was markedly decreased $(n=10 ; p<0.01)$ (Figure 5D). Both the expression pattern of phospho-Stat 3 and the effect of acinar cell-specific knockout of Stat3 indicate that CNTF signals via Stat3 in acinar cells to initiate their reprogramming to beta-like cells.

\section{DISCUSSION}

Here we demonstrate that a combination of the cytokines EGF and CNTF can reverse chemically induced diabetes in young adult mice that have been hyperglycemic for 35 days. Cytokine-treated mice showing normalized glycemia also showed a marked increase in beta 
cell mass and pancreas insulin content, and their newly formed beta-like cells were glucoseresponsive. Restoration of beta cell mass and normoglycemia resulted mainly from conversion of differentiated acinar cells to functional beta-like cells: acinar-to-beta reprogramming produced $39.1 \pm 8.2 \%$ of the original number of beta cells, whereasa other sources including pre-existing beta and duct cells contributed an additional $4 \%$. As the restored normoglycemia was durable, cytokine-induced reprogramming of acinar cells generates a lasting population of functional beta-like cells.

Compared with the previous report on reprogramming of acinar cells with adenoviruses expressing islet transcription factors ${ }^{16}$, our strategy avoids the use of viruses and associated risks. Moreover, our results contrast with previous reports showing that acinar cells do not spontaneously contribute to neoformation of beta cells following partial duct ligation, partial pancreatectomy or caerulein-induced pancreatitis ${ }^{15}$. In addition, although treatment with EGF and gastrin starting $24 \mathrm{~h}$ after ALX-mediated induction of hyperglycemia was reported to restore normoglycemia ${ }^{14}$, our own unpublished data indicate that EGF and gastrin failed to ameliorate the long term hyperglycemia in $\mathrm{ALX}_{35 \mathrm{~d}}$ mice, possibly because this combination of cytokines may act solely by protecting residual beta cells as it neither activated Ngn3 gene expression nor induced acinar to beta cell reprogramming.

The present study sheds light on the actions of EGF and CNTF in the pancreas. Mice with targeted inactivation of EGF show no pancreatic abnormalities, possibly due to the expression of other ErbB ligands that may act in a redundant manner ${ }^{28}$. In the adult mouse pancreas, islet and duct cells express EGFR but acinar cells do not ${ }^{29}$. CNTF is expressed by pancreatic beta cells ${ }^{30}$, and we detected CNTFRa, a component of its receptor, in acinar and duct cells (unpublished data). CNTF signals through the heterotrimer of CNTFRa, LIF receptor beta and gp $130^{31,32}$, induces weight loss in rodents ${ }^{33,34}$ and improves insulin sensitivity in models of type II diabetes eventually leading to a correction of hyperglycemia ${ }^{35,36}$. Accordingly, an effect of CNTF on insulin action may explain why we observed near normoglycemia despite only $40 \%$ rather than complete regeneration of the beta cell mass in $\mathrm{ALX}_{35 \mathrm{~d} / \mathrm{CK}^{\text {resp }}}$ mice. CNTF also acts directly on beta cells to attenuate insulin release and to block Interleukin $1 \beta$-mediated beta cell death ((through STAT3SOCS3 signaling) $)^{37,38}$. However, genetic lineage tracing of pre-existing and cycling beta cells indicated that direct effects of CNTF on beta cells could only account for about $10 \%$ of all recovered insulin ${ }^{+}$cells in $\mathrm{ALX}_{35 \mathrm{~d} / \mathrm{CK}}$ mice.

We observed a positive correlation between activation of STAT3 and normalization of hyperglycemia in response to cytokine treatment. Both EGF and CNTF are reported to signal through STAT3 ${ }^{39}$, although treatment with neither EGF nor CNTF independently restored normoglycemia. In addition, selective removal of STAT3 from pre-existing acinar cells prevented a correction of blood glucose levels as well as cytokine-induced reprogramming of acinar cells to beta-like cells. As STAT3 activation after cytokine treatment was similar in all of the different strains studied, the cytokine effects in this experimental model are strain-independent.

EGF and CNTF treatment of hypoglycemic mice activated expression of the pro-endocrine embryonic transcription factor $\mathrm{Ngn} 3^{40,41}$. $\mathrm{YFP}^{+}$cells were dispersed throughout the acinar 
cell compartment of the pancreas from $\mathrm{ALX}_{35 \mathrm{~d} / \mathrm{CK}} \mathrm{Ngn} 3^{\mathrm{YFP}}$ mice and were 10-fold more frequent than $\mathrm{Ngn} 3^{\mathrm{YFP}}$ cells induced by partial duct ligation ${ }^{7}$. A correlation between the number of $\mathrm{YFP}^{+}$cells in the pancreas of long term diabetic Ngn3 ${ }^{\mathrm{YFP}}$ mice and the responsiveness of these mice to the cytokine treatment suggests that a minimal number of $\mathrm{Ngn}^{+}$cells is necessary to drive beta cell regeneration; in $\mathrm{ALX}_{35 \mathrm{~d} / \mathrm{CK}}{ }^{\text {unresp }}$ mice the number of $\mathrm{Ngn}^{+}$cells, possibly in addition to the abundance of $\mathrm{Ngn} 3$ in each cell, may be below this putative threshold.

The link between activation of Ngn3 gene expression in facultative progenitor cells and adult beta cell formation, however, remains controversial as beta cells per se produce low levels of $\mathrm{Ngn} 3^{42}$. Permanent genetic lineage tracing of $\mathrm{Ngn} 3^{+}$cells revealed that the majority of newly formed insulin ${ }^{+}$cells in $\mathrm{ALX}_{35 \mathrm{~d} / \mathrm{CK}^{\text {resp }}}$ mice derived from Ngn3expressing acinar cells. In addition to the low beta cell cycle activity, the lineage tracing data also suggest that migration, rather than division, of beta-like cells is a primary event during islet formation in our model. Indeed, while generation of new small islet-like clusters was already observed only 4 days after EGF and CNTF treatment, large islets were already observed at day 7. The observation that alpha cells were dispersed over the new islets rather than at their periphery, supports continuous migration of new beta-like cells to islet remnants rather than fission of small islets. In our model YFP was only detected in a very small number of the endocrine beta cells on pancreas tissue sections of $\mathrm{NG}_{\mathrm{CTR}}$ and $\mathrm{ALX} \mathrm{X}_{\mathrm{CTR}}$ mice, and Ngn3-encoding transcripts were barely detectable in granulated endocrine islet cells isolated from $\mathrm{ALX}_{35 \mathrm{~d} / \mathrm{CK}}$ mice; as such these observations suggest a minor role for Ngn3 expression in beta cells in our model. However, when Ngn3 expression was deleted specifically from acinar cells prior to the cytokine treatment, $\mathrm{ALX}_{35 \mathrm{~d} / \mathrm{CK}}$ mice remained more hyperglycemic and the number of newly formed insulin ${ }^{+}$cells was markedly decreased relative to Ngn3 wild-type mice. Therefore, activation of $\mathrm{Ngn} 3$ gene expression is required for the complete transdifferentiation of acinar cells to beta-like cells.

The regenerative process observed here may be compared to other examples of directed adult tissue regeneration. For example, postnatal mammalian digit regeneration may occur through BMP-dependent signaling ${ }^{43,44}$ to tissue resident stem cells rather than through activation of pluripotent blastema cells as seen in amphibian limb regeneration ${ }^{45}$.

Specifically, fate restricted progenitors could be marked by Msx1 expression and represent a conserved cellular mode for mammalian regeneration ${ }^{46,47}$. Despite these previous reports of extreme tissue regeneration in mammals ${ }^{44,47}$, the mammalian capacity for tissue regeneration by cellular reprogramming or transdifferentiation remains unclear. Nevertheless, our data demonstrate that pharmacologic treatment can promote clinically meaningful plasticity in the pancreas in live adult mice. This model may be used to study the signaling pathways involved in acinar-to-beta-like cell reprogramming, and to identify additional compounds and targets that may promote this process in a therapeutic setting.

\section{ONLINE METHODS}

\section{Mice}

All mouse experiments were performed according to our institutional "Ethical Committee for Animal Experiments" following the national guidelines and regulations. All mice strains 
were described previously 5, 8, 19, 27, 42: RipCre $^{\mathrm{ERT}} \mathrm{R} 26^{\mathrm{LacZ}}$, ElaCre ${ }^{\mathrm{ERT}} \mathrm{R} 26^{\mathrm{LacZ}}$,

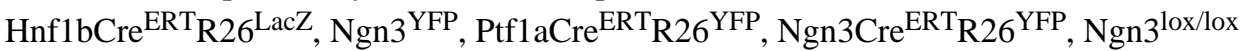
and Stat3 $3^{\text {lox/lox }}$. The beta cell toxins alloxan (ALX) and streptozotocin (STZ) were injected in 8 and 13 week (in case of genetic lineage tracing) old male mice via the dorsal tail vein (at $70 \mathrm{mg} \mathrm{ALX/kg}$ body weight) and into the peritoneum (at $200 \mathrm{mg} \mathrm{STZ} / \mathrm{kg}$ body weight). Tail vein blood glucose level (Glucocard X-meter, Arkray Inc.) and body weight were evaluated daily or weekly, following 2 hours of fasting. Tamoxifen (TAM, Sigma) was prepared at $10 \mathrm{mg} / \mathrm{ml}$ in corn oil (Sigma). For tracing studies in adult mice, a total of $20 \mathrm{mg}$ of TAM was given s.c. in 5 doses (each $4 \mathrm{mg}$ ) over a 2 week period, unless stated otherwise. A washout period of 24 days was maintained (unless stated otherwise) to assure TAM clearance. Of all mice rendered diabetic, $44.3 \pm 6.7 \%$ survived the diabetic period of 35 days and were included in subsequent experiments.

\section{Cytokines}

Human recombinant Epidermal Growth Factor (Sigma) was diluted in $10 \mathrm{mmol} / \mathrm{L}$ acetic acid solution to a final concentration of $1 \mathrm{mg} / \mathrm{ml}$. Human recombinant Ciliary Neurotrophic Factor (BioVision) was diluted to a final concentration of $2 \mathrm{mg} / \mathrm{ml}$. The mixture was injected into mini-osmotic pumps (Alzet 1007D) (Charles River Laboratories) to obtain a flux rate of $10 \mathrm{mg} / \mathrm{kg}$ body weight/hour for EGF and $23.8 \mathrm{mg} / \mathrm{kg}$ body weight $/$ hour for CNTF. Pumps with cytokines or vehicle (composed of $5 \mathrm{mmol} / \mathrm{L}$ acetic acid solution) were implanted intraperitoneally at 35 days post ALX or STZ injection. The manufacturer determined the pump release time to be 7 days. The exact dose used for EGF was derived from previous publications ${ }^{14}$, while the CNTF dose was derived from a dose-response experiment using 4 doses (5.95, 11.90, 23.8 and $35.70 \mathrm{mg} / \mathrm{kg}$ body weight).

\section{Cell sorting}

For FACS analysis, the dissected pancreas was digested with collagenase $(0.8 \mathrm{mg} / \mathrm{ml}$, Sigma), dissociated to single cells by addition of trypsin $(1 \mathrm{mg} / \mathrm{ml}$, Sigma) and DNAse $(0.4$ $\mathrm{mg} / \mathrm{ml}$, Sigma), passed through a $66 \mu \mathrm{m}$ filter and resuspended in isolation medium (Lonza). Propidium Iodide (Molecular Probes, Life Sciences) $(0.5 \mathrm{mg} / \mathrm{ml})$ and Hoechst 33342 (Molecular Probes, Life Sciences) $(1 \mathrm{mg} / \mathrm{ml})$ were added for live/dead analyses. To visualize granulated beta cells, a $\mathrm{Zn}^{2+}$ binding dye $N$-(6-Methoxy-8-Quinolyl)- $p$-Toluenesulfonamide (TSQ) was added $(1 \mathrm{mg} / \mathrm{ml})$.

\section{RNA Analysis}

Total RNA was isolated from cells (RNeasy, Qiagen; Picopure, Arcturus) or tissues (TRIzol, Invitrogen). Only RNA with RNA Integrity Number (RIN) $\geq 7$ (2100 BioAnalyzer, Agilent) was further analyzed. cDNA synthesis and RT-PCR were done as described ${ }^{48}$ using genespecific primers. Primer and probe sequences are present in Table S1. To avoid interference from contaminating genomic DNA, all primer sets were designed to span at least one intron. All targets were amplified using 30 cycles by conventional RT-PCR (except for CycloA, 22 cycles) and 40 cycles by RT-qPCR (Applied Biosystems). Data were analyzed using the Sequence Detection Systems Software, Version 1.9.1 (Applied Biosystems). 


\section{Protein analysis}

Samples for immunohistochemistry (IHC) were overnight fixed in $4 \%$ formaldehyde (FA), embedded in paraffin and cut to $4-5 \mu \mathrm{m}$ tissue sections. Primary antibodies: guinea pig polyclonal anti-insulin and rabbit polyclonal anti-glucagon (kind gift from $\mathrm{C}$ Van Schravendijk, Vrije Universiteit Brussel, Brussels); rabbit polyclonal antibodies against $\mathrm{Ngn} 3^{49}$, rabbit polyclonal antibodies against $\mathrm{Pdx} 1^{50}$; rabbit polyclonal antibodies against Ki67 (ACK02, Novocastra) ${ }^{17}$ and amylase (A8273, Sigma) ${ }^{17}$, rat polyclonal antibodies against keratin-19 (TromaIII, Hybridoma Bank, Iowa) ${ }^{17}$ and goat polyclonal anti-GFP (ab6658, Abcam $)^{22}$. IdU incorporation was visualized using mouse anti-BrdU antibody (347580, Becton Dickinson) ${ }^{7}$. Antigen retrieval in paraffin sections for detection of GFP, K19, Pdx1 and Ngn3 was heat- or enzyme-mediated. Secondary antibodies for indirect fluorescent staining were Cy3-or FITC-labeled anti-rabbit, anti-rat, anti-mouse, anti-goat and anti-guinea pig (all from Jackson ImmunoResearch Labs). Nuclei were labeled by Hoechst 33342 (4 mg/ml, Sigma). A minimum of 2000 cells was analyzed per condition.

\section{Metabolic studies}

Mice were fasted during 4 hours and injected intraperitoneally (i.p.) with glucose $(2 \mathrm{~g}$ per $\mathrm{kg}$ body weight) or insulin ( $0.75 \mathrm{U}$ per kg body weight) for glucose and insulin tolerance tests, respectively, and blood glucose concentration was measured from tail vein blood with a portable glucometer. For insulin secretion tests, mice were fasted for 6 hours, i.p. injected with glucose ( $2 \mathrm{~g}$ per kg body weight) and at 0 and 30 minutes blood was sampled from retroorbital plexus with a heparinized microvette (Sarstedt AG \& Co.). Plasma insulin and glucagon concentration were determined with the Mouse Linco Insulin ELISA kit (Millipore) and the chemiluminescent Glucagon ELISA kit (Millipore), respectively. Total pancreas insulin content was determined using a mouse insulin radioimmunoassay kit (Linco Research Inc). Lean and fat mass were determined using EchoMRI. For GSIS analysis, pancreatic islets were isolated by collagenase digestion, handpicked and pooled.

\section{Bisulfite methylation analysis}

DNA was isolated by digestion buffer supplemented with proteinase K overnight, followed by phenol-chloroform extraction and ethanol precipitation. DNA subjected to bisulfite treatment performed with the EZ DNA Methylation-Direct kit (ZYMO RESEARCH) according to the manufacturer's instructions. Following treatment DNA was amplified using primer sets that encompass the promoter region of Amylase2b insulin and Glut2 genes The primers used were the following for Amy2b (-155+151), $5^{\prime}$ ATGGTTTTAGAGGGTTTTTAG 3' (forward), 5' CCTCCAAATCCCTTAAAAA 3' (reverse), for Insulin (-411-168) 5' TTTAAGTGGGATATGGAAAGAGAGATA 3' (forward), 5' ACTACAATTTCCAAACACTTCCCTAATA 3'(reverse), for Glut2 (-518 -290) 5' GAAAGTATATTGTTATTATTTATTGAG 3' (forward) 5' ACTAAAAAAAACAACCTATAAAATC $3^{\prime}$ (reverse). Reaction conditions of PCR were 5 cycles of $95{ }^{\circ} \mathrm{C} 1 \mathrm{~min}, 52{ }^{\circ} \mathrm{C} 3 \mathrm{~min}, 72{ }^{\circ} \mathrm{C} 3 \mathrm{~min}$ followed by 35 cycles of $95{ }^{\circ} \mathrm{C} 45 \mathrm{~s}, 52{ }^{\circ} \mathrm{C}$ $1 \mathrm{~min}, 72{ }^{\circ} \mathrm{C} 1 \mathrm{~min}$ followed by $7 \mathrm{~min}$ at $72{ }^{\circ} \mathrm{C}$. Purified PCR products (Roche high pure PCR kit) were cloned into pGEM vectors (Promega) before sequencing. 


\section{Beta cell number, proliferation and mass analysis}

Morphometry of the insulin area and determination of the beta cell fraction were by sectioning and analyzing $2 \%$ of the total pancreas. Counting of $\mathrm{IdU}^{+}$and $\mathrm{Ki} 67^{+}$beta cells were performed by serially sectioning of the entire pancreas followed by staining and counting every 30 th section. A minimum of 4,000 insulin ${ }^{+}$cells were counted per pancreas.

\section{Image analysis}

Images were acquired with a normal (Zeiss Axioplan 2 with Hamamatsu C10600 ORKA-R ${ }^{2}$ camera) or confocal multiphoton (Zeiss LSM710 NLO with TiSa laser) microscopy. Images were analyzed using Smartcapture 3 (version 3.0.8) and Photoshop/Illustrator CS5. Confocal images were processed using Improvision VolocityLE and Zeiss Zen software.

\section{Data analysis and Biostatistics}

All values are depicted as average \pm standard error of the mean (s.e.m.) from $\geq 4$ independent experiments. Statistical significance is defined as $\mathrm{p}<0.05$. Sample sizes are provided in the figure legends.

Blood glucose and bodyweight measurements were taken during the hyperglycemic period before treatment and at the time of cytokine treatment (data in figures $1 \mathrm{~B}, 1 \mathrm{E}, 5 \mathrm{E}, \mathrm{S} 1 \mathrm{G}$, $\mathrm{S} 1 \mathrm{H}, \mathrm{S6C})$. Individual animals in these experiments were measured 15 times each on days $-1,0,1,7,14,21,28,35,36,37,38,39,40,41,42$. Alloxan injection was at day 0 , and cytokine treatment period at day 35 . For longer-term post-treatment follow-up, blood glucose levels and body weight were measured once a week.

Dynamic measurement of blood glucose levels was performed during glucose or insulin tolerance tests (data in figures 1C and 1D). Following glucose or insulin challenge performed at the end of the 7 days treatment period (day 42), every mouse was measured 7 times $(0,10,20,30,60,90,120$ minutes after glucose or insulin injection).

Static measurement of INS $^{+}$cell fraction, area and proliferation was on 6 animals per experimental group assayed on days 7, 16, 37, 39, 42 and 98 (data in figures 1I, S1I, S1K).

No data points were missing due to human error and no outliers were excluded. However, animals were excluded from the study when they died during the hyperglycemic period prior to cytokine-treatment or when their fasting blood glucose measurement at day 35 was $<25 \mathrm{mmol} / \mathrm{l}$. All diabetic animals were randomly assigned to either control or treatment groups (no blinding was performed).

Some attrition did occur following cytokine treatment among the non-responder mice that died from hyperglycemia. The data obtained from these animals were included up to the point at which they were lost. The Linear Mixed Effects Model is able to appropriately deliberate missing data, provided they can be considered as missing at random. Overall, less than $5 \%$ of all animals included in the study were lost to attrition during the period of cytokine treatment and attrition was equal amongst different hyperglycemic groups. When mice were followed-up for extended periods after pump implantation (vehicle or cytokine treated) attrition did become a major factor because the control animals that only received 
vehicle treatment finally all succumbed to hyperglycemia. We therefore did not perform formal statistical analyses of these extended period data.

All data were statistically analyzed by unpaired Student t-test (Figures 1H, 2C, 2E, S2B), 1way ANOVA (Figures 1F, 3B, 4B, 4C, S1C, S1D, S3B, S4A, S5B), 2-way ANOVA with Bonferroni post hoc test (1D, 1G, 1I, 3G, 3H, 5D, S1I, S1K, S6A, S6B, S6C) or a Linear Mixed Effects Model (Figures 1B, 1C, 1E, 5C, S1A, S1B, S1G, S1H, S6E). The Linear Mixed Effects Model included time and group as categorical predictors as well as a time by group interaction. A random mouse effect was added to explicitly account for within and between mouse variance. Time was modeled as categorical predictor, akin to repeated measures ANOVA, in order to avoid any a priori assumptions of specific temporal patterns in the outcome. Primary statistical testing was determined via detection of a statistically significant time-by-group interaction (Chi-square likelihood ratio test comparing models with and without the interaction term - both fitted by maximum likelihood). A statistically significant time-by-group interaction would indicate a difference in the temporal evolution of the outcome between the two groups.

The residuals of all fitted models were assessed for approximate normality using QQ-plots. The majority of QQ-plots indicated that the residuals were approximately normal.

A priori power calculations-Samples size was a priori determined by power analysis to discriminate hypothetical differences of $50 \%$ or greater (type I error: 0.05 ; type II error: $0.01)$.

Graphpad Prism 5 for Mac OSX version 5.0f was used for ANOVA and Student t-test; R 3.0.1 (http://www.r-project.org/) and the nlme library was used for Linear Mixed Effects model

\section{Supplementary Material}

Refer to Web version on PubMed Central for supplementary material.

\section{Acknowledgments}

Special thanks to Veerle Laurysens, Ann Demarré, Erik Quartier, Jan De Jonge for technical advice and assistance, Daniel Pipeleers for logistic support and Gao Bin for the Stat3lox/lox mouse strain. We thank Dr. John Kornak for support on biostatistics. LBa is a postdoctoral fellow of the Research Foundation - Flanders (FWO). Financial support was obtained from the Research Foundation - Flanders (FWO) (HH, LBa and LBo), the Juvenile Diabetes Research Foundation (HH and LBo), DON Foundation (www.sdon.nl) (HH), the European Foundation for the Study of Diabetes (EFSD) (LBa, PB and LBo), the European Union Sixth (\#LSHB-CT-2005-512145), Seventh (HEALTH-F5-2009-241883) Framework Program (HH and LBo), Diabetesfonds Nederland (HH), NIH U19 DK 042502 and U01 DK 089570 (CVEW and FCP), P30 DK063720 and U01 DK089541 (MSG).

\section{References}

1. Brockes JP, Kumar A. Comparative aspects of animal regeneration. Annu Rev Cell Dev Biol. 2008; 24:525-549. [PubMed: 18598212]

2. Slack JM. Metaplasia and transdifferentiation: from pure biology to the clinic. Nat Rev Mol Cell Biol. 2007; 8:369-378. [PubMed: 17377526]

3. Baddour JA, Sousounis K, Tsonis PA. Organ repair and regeneration: an overview. Birth Defects Res C Embryo Today. 2012; 96:1-29. [PubMed: 22457174] 
4. Sanchez Alvarado A, Tsonis PA. Bridging the regeneration gap: genetic insights from diverse animal models. Nat Rev Genet. 2006; 7:873-884. [PubMed: 17047686]

5. Dor Y, Brown J, Martinez OI, Melton DA. Adult pancreatic beta-cells are formed by selfduplication rather than stem-cell differentiation. Nature. 2004; 429:41-46. [PubMed: 15129273]

6. Nir T, Melton DA, Dor Y. Recovery from diabetes in mice by beta cell regeneration. J Clin Invest. 2007; 117:2553-2561. [PubMed: 17786244]

7. Xu X, et al. Beta cells can be generated from endogenous progenitors in injured adult mouse pancreas. Cell. 2008; 132:197-207. [PubMed: 18243096]

8. Solar M, et al. Pancreatic exocrine duct cells give rise to insulin-producing beta cells during embryogenesis but not after birth. Dev Cell. 2009; 17:849-860. [PubMed: 20059954]

9. Kopinke D, et al. Lineage tracing reveals the dynamic contribution of Hes 1+ cells to the developing and adult pancreas. Development. 2011; 138:431-441. [PubMed: 21205788]

10. Kopinke D, Murtaugh LC. Exocrine-to-endocrine differentiation is detectable only prior to birth in the uninjured mouse pancreas. BMC Dev Biol. 2010; 10:38. [PubMed: 20377894]

11. Furuyama K, et al. Continuous cell supply from a Sox9-expressing progenitor zone in adult liver, exocrine pancreas and intestine. Nat Genet. 2011; 43:34-41. [PubMed: 21113154]

12. Kopp JL, et al. Sox9+ ductal cells are multipotent progenitors throughout development but do not produce new endocrine cells in the normal or injured adult pancreas. Development. 2011; 138:653-665. [PubMed: 21266405]

13. Thorel F, et al. Conversion of adult pancreatic alpha-cells to beta-cells after extreme beta-cell loss. Nature. 2010; 464:1149-1154. [PubMed: 20364121]

14. Rooman I, Bouwens L. Combined gastrin and epidermal growth factor treatment induces islet regeneration and restores normoglycaemia in C57B16/J mice treated with alloxan. Diabetologia. 2004; 47:259-265. [PubMed: 14666367]

15. Desai BM, et al. Preexisting pancreatic acinar cells contribute to acinar cell, but not islet beta cell, regeneration. J Clin Invest. 2007; 117:971-977. [PubMed: 17404620]

16. Zhou Q, Brown J, Kanarek A, Rajagopal J, Melton DA. In vivo reprogramming of adult pancreatic exocrine cells to beta-cells. Nature. 2008; 455:627-632. [PubMed: 18754011]

17. Rooman I, et al. Expression of the Notch signaling pathway and effect on exocrine cell proliferation in adult rat pancreas. Am J Pathol. 2006; 169:1206-1214. [PubMed: 17003479]

18. Rooman I, Heremans Y, Heimberg H, Bouwens L. Modulation of rat pancreatic acinoductal transdifferentiation and expression of PDX-1 in vitro. Diabetologia. 2000; 43:907-914. [PubMed: 10952464]

19. Means AL, et al. Pancreatic epithelial plasticity mediated by acinar cell transdifferentiation and generation of nestin-positive intermediates. Development. 2005; 132:3767-3776. [PubMed: $16020518]$

20. Lardon J, et al. Plasticity in the adult rat pancreas: transdifferentiation of exocrine to hepatocytelike cells in primary culture. Hepatology. 2004; 39:1499-1507. [PubMed: 15185290]

21. Baeyens L, et al. Notch signaling as gatekeeper of rat acinar-to-beta-cell conversion in vitro. Gastroenterology. 2009; 136:1750-1760. e1713. [PubMed: 19208356]

22. Baeyens L, et al. Ngn3 expression during postnatal in vitro beta cell neogenesis induced by the JAK/STAT pathway. Cell Death Differ. 2006; 13:1892-1899. [PubMed: 16514419]

23. Baeyens L, et al. In vitro generation of insulin-producing beta cells from adult exocrine pancreatic cells. Diabetologia. 2005; 48:49-57. [PubMed: 15616797]

24. Minami K, et al. Lineage tracing and characterization of insulin-secreting cells generated from adult pancreatic acinar cells. Proc Natl Acad Sci US A. 2005; 102:15116-15121.

25. Szkudelski T. The mechanism of alloxan and streptozotocin action in B cells of the rat pancreas. Physiol Res. 2001; 50:537-546. [PubMed: 11829314]

26. Pan FC, et al. Spatiotemporal patterns of multipotentiality in Ptf1a-expressing cells during pancreas organogenesis and injury-induced facultative restoration. Development. 2013; 140:751764. [PubMed: 23325761]

27. Mellitzer G, et al. Pancreatic islet progenitor cells in Neurogenin 3-yellow fluorescent protein knock-add-on mice. Molecular Endocrinology. 2004; 18:2765-2776. [PubMed: 15297605] 
28. Miettinen P, Ormio P, Hakonen E, Banerjee M, Otonkoski T. EGF receptor in pancreatic beta-cell mass regulation. Biochem Soc Trans. 2008; 36:280-285. [PubMed: 18481942]

29. Miettinen PJ, et al. Impaired migration and delayed differentiation of pancreatic islet cells in mice lacking EGF-receptors. Development. 2000; 127:2617-2627. [PubMed: 10821760]

30. Wadt KA, et al. Ciliary neurotrophic factor potentiates the beta-cell inhibitory effect of IL-1beta in rat pancreatic islets associated with increased nitric oxide synthesis and increased expression of inducible nitric oxide synthase. Diabetes. 1998; 47:1602-1608. [PubMed: 9753298]

31. Ip NY, et al. CNTF and LIF act on neuronal cells via shared signaling pathways that involve the IL-6 signal transducing receptor component gp130. Cell. 1992; 69:1121-1132. [PubMed: 1617725]

32. Murakami M, et al. IL-6-induced homodimerization of gp130 and associated activation of a tyrosine kinase. Science. 1993; 260:1808-1810. [PubMed: 8511589]

33. Lambert PD, et al. Ciliary neurotrophic factor activates leptin-like pathways and reduces body fat, without cachexia or rebound weight gain, even in leptin-resistant obesity. Proc Natl Acad Sci U S A. 2001; 98:4652-4657. [PubMed: 11259650]

34. Gloaguen I, et al. Ciliary neurotrophic factor corrects obesity and diabetes associated with leptin deficiency and resistance. Proc Natl Acad Sci U S A. 1997; 94:6456-6461. [PubMed: 9177239]

35. Watt MJ, et al. CNTF reverses obesity-induced insulin resistance by activating skeletal muscle AMPK. Nat Med. 2006; 12:541-548. [PubMed: 16604088]

36. Sleeman MW, et al. Ciliary neurotrophic factor improves diabetic parameters and hepatic steatosis and increases basal metabolic rate in db/db mice. Proc Natl Acad Sci U S A. 2003; 100:1429714302. [PubMed: 14610276]

37. Rezende LF, Santos GJ, Santos-Silva JC, Carneiro EM, Boschero AC. Ciliary neurotrophic factor (CNTF) protects non-obese Swiss mice against type 2 diabetes by increasing beta cell mass and reducing insulin clearance. Diabetologia. 2012; 55:1495-1504. [PubMed: 22349107]

38. Rezende LF, Vieira AS, Negro A, Langone F, Boschero AC. Ciliary neurotrophic factor (CNTF) signals through STAT3-SOCS3 pathway and protects rat pancreatic islets from cytokine-induced apoptosis. Cytokine. 2009; 46:65-71. [PubMed: 19272793]

39. Kamakura S, et al. Hes binding to STAT3 mediates crosstalk between Notch and JAK-STAT signalling. Nat Cell Biol. 2004; 6:547-554. [PubMed: 15156153]

40. Gradwohl G, Dierich A, LeMeur M, Guillemot F. neurogenin3 is required for the development of the four endocrine cell lineages of the pancreas. Proceedings of the National Academy of Sciences of the United States of America. 2000; 97:1607-1611. [PubMed: 10677506]

41. Apelqvist A, et al. Notch signalling controls pancreatic cell differentiation. Nature. 1999; 400:877881. [PubMed: 10476967]

42. Wang S, et al. Sustained Neurog3 expression in hormone-expressing islet cells is required for endocrine maturation and function. Proc Natl Acad Sci U S A. 2009; 106:9715-9720. [PubMed: 19487660]

43. $\mathrm{Yu}$ L, et al. BMP signaling induces digit regeneration in neonatal mice. Development. 2010; 137:551-559. [PubMed: 20110320]

44. Han M, Yang X, Farrington JE, Muneoka K. Digit regeneration is regulated by Msx1 and BMP4 in fetal mice. Development. 2003; 130:5123-5132. [PubMed: 12944425]

45. Rinkevich Y, Lindau P, Ueno H, Longaker MT, Weissman IL. Germlayer and lineage-restricted stem/progenitors regenerate the mouse digit tip. Nature. 2011; 476:409-413. [PubMed: 21866153]

46. Lehoczky JA, Robert B, Tabin CJ. Mouse digit tip regeneration is mediated by fate-restricted progenitor cells. Proc Natl Acad Sci U S A. 2011; 108:20609-20614. [PubMed: 22143790]

47. Odelberg SJ, Kollhoff A, Keating MT. Dedifferentiation of mammalian myotubes induced by msx1. Cell. 2000; 103:1099-1109. [PubMed: 11163185]

48. Mellitzer G, et al. IA1 is NGN3-dependent and essential for differentiation of the endocrine pancreas. Embo J. 2006; 25:1344-1352. [PubMed: 16511571]

49. Schwitzgebel VM, et al. Expression of neurogenin3 reveals an islet cell precursor population in the pancreas. Development. 2000; 127:3533-3542. [PubMed: 10903178] 
50. Wright CV, Schnegelsberg P, De Robertis EM. XlHbox 8: a novel Xenopus homeo protein restricted to a narrow band of endoderm. Development. 1989; 105:787-794. [PubMed: 2574662] 

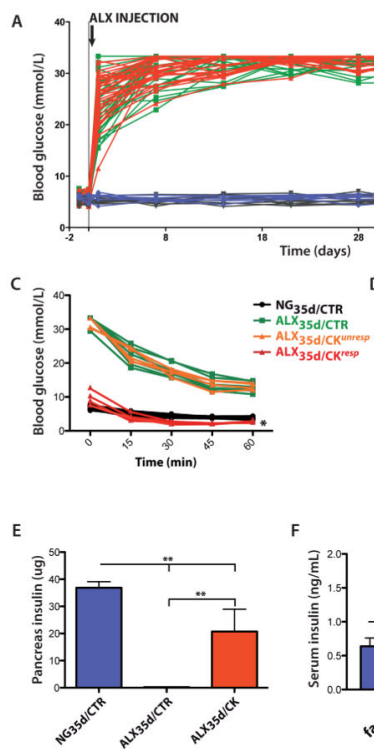

$\mathrm{F}$
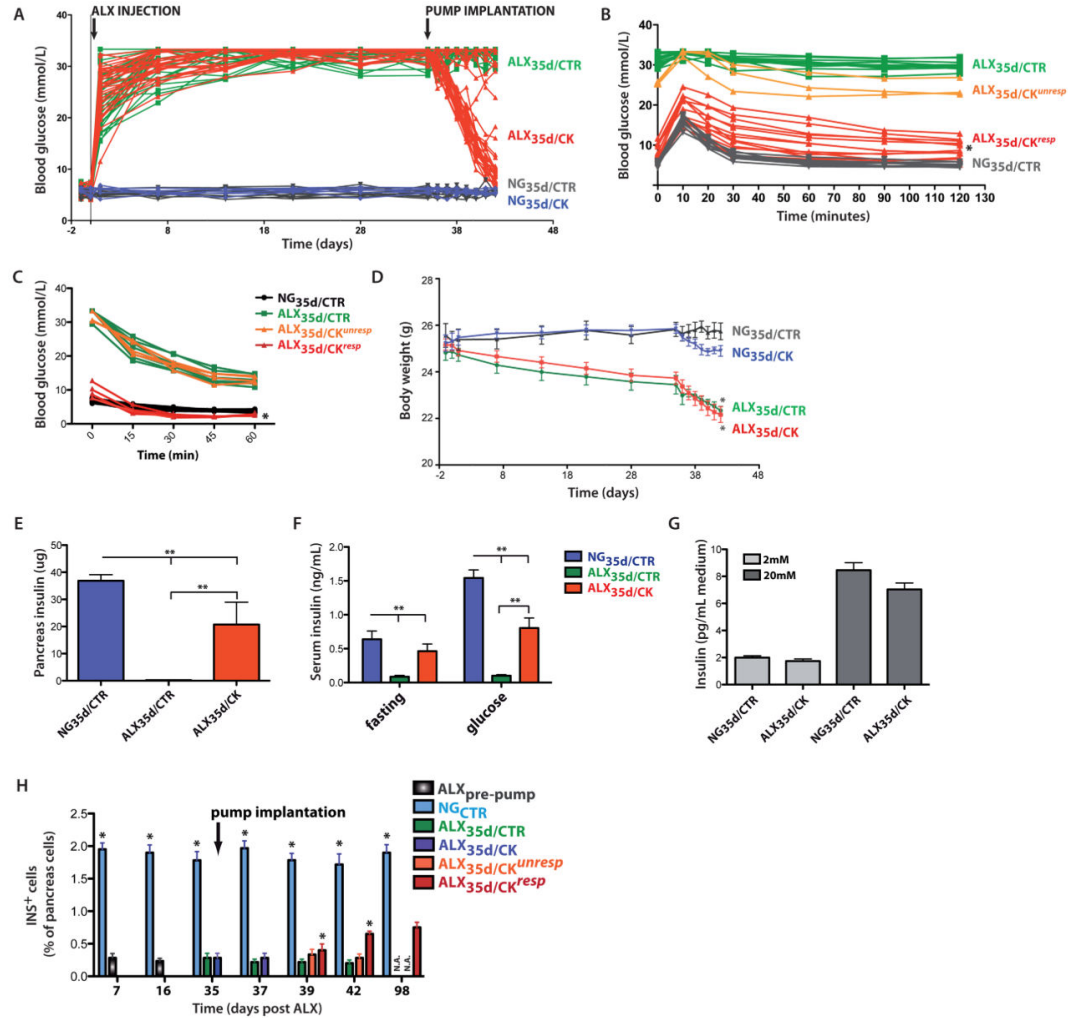

Figure 1. Chronic diabetes in mice can be reverted by transient release of EGF and CNTF

(A) Hyperglycemia was induced by intravenous (i.v.) injection of a single dose of the beta cell toxin alloxan (ALX) in 8-13 week old male mice of mixed background. Glycemia was then assayed by a portable glucometer in blood collection from the tail vein on a daily or weekly basis. Where indicated, 35 days after ALX injection, osmotic mini-pumps loaded with EGF and CNTF $\left(\mathrm{ALX}_{35 \mathrm{~d} / \mathrm{CK}}, \mathrm{n}=35\right)$ or vehicle $\left(\mathrm{ALX}_{35 \mathrm{~d} / \mathrm{CTR}}, \mathrm{n}=35\right)$ were implanted intraperitoneally (i.p.). $\mathrm{NG}_{35 \mathrm{~d} / \mathrm{CTR}}(\mathrm{n}=10)$ and $\mathrm{NG}_{35 \mathrm{~d} / \mathrm{CK}}(\mathrm{n}=10)$ mice were not treated with ALX and were implanted with vehicle and cytokine-loaded pumps, respectively. (B) I.p. glucose tolerance test (IPGTT). $2 \mathrm{~g}$ glucose per $\mathrm{kg} \mathrm{BW}$ was injected and clearance in blood was measured at indicated time points to indirectly measure the glucose responsiveness of insulin secretion by beta cells (*: $\mathrm{p}<0.001, \mathrm{ALX}_{35 \mathrm{~d} / \mathrm{CK}}$ vs $\mathrm{ALX}_{35 \mathrm{~d} / \mathrm{CTR}}$ mice; $\mathrm{n}=15$ each).

(C) Insulin Tolerance Test (ITT). Blood glucose levels following i.v. injection of $0.75 \mathrm{U}$ insulin per kg BW were measured. (*p<0.01, $\operatorname{ALX}_{35 \mathrm{~d} / \mathrm{CK}}{ }^{\text {resp }}(\mathrm{n}=5)$ vs. $\mathrm{NG}_{35 \mathrm{~d} / \mathrm{CTR}}$ mice $(\mathrm{n}=9))$. (D) Body weight was measured at indicated time points. Differences in body weight between ALX-treated and untreated mice were not statistically significant until implantation of the pump on day 35 ( $p>0.05$ from day 0 to day $34, p<0.05$ from day 35 to day 42 ,

$\mathrm{ALX}_{35 \mathrm{~d}} \mathrm{vs} \mathrm{NG}_{35 \mathrm{~d}}$ mice). (E) Total pancreas insulin content was measured by radio-immuno assay on tissue extracts at $\mathbf{7}$ days after pump implantation. (F) Serum insulin was measured 7 days after pump implantation, at time point 0 (after $6 \mathrm{~h}$ fasting) and 30 minutes after i.p. injection of $2 \mathrm{~g}$ glucose per $\mathrm{kg} \mathrm{BW}$ (glucose) (**: $\mathrm{p}<0.01$ ). (G) Insulin secretion by islets isolated from $\mathrm{NG}_{35 \mathrm{~d} / \mathrm{CTR}}$ and $\mathrm{ALX}_{35 \mathrm{~d} / \mathrm{CK}}$ mice (7 days after pump implantation). Islets were stimulated with 2 or $20 \mathrm{mmol} / \mathrm{L}$ glucose and insulin was measured 2 hours later. (H) Insulinexpressing $\left(\mathrm{INS}^{+}\right)$beta cells were quantified by conventional morphometry at the indicated 
time points after ALX injection. No $\mathrm{ALX}_{35 \mathrm{~d} / \mathrm{CTR}}$ or $\mathrm{ALX}_{35 \mathrm{~d} / \mathrm{CK}}$ unresp animals survived until day 98 (N.A.). At all time points the percentage $\mathrm{INS}^{+}$cells was significantly higher in $\mathrm{NG}_{\mathrm{CTR}}$ mice than in ALX mice (*: $\mathrm{p}<0.01 ; \mathrm{n}=6$ for each data bar). 


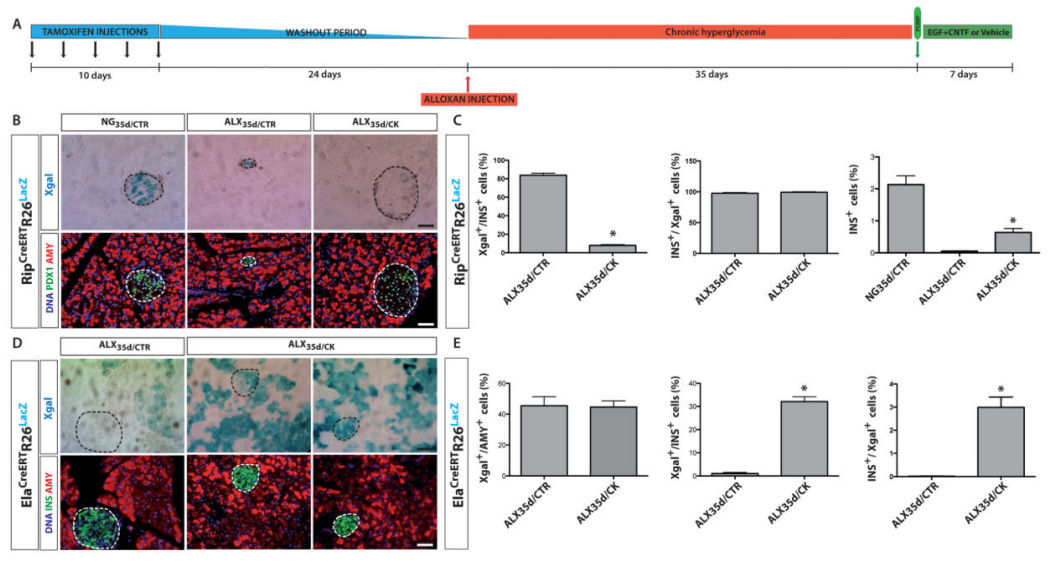

Figure 2. Acinar cells are the primary source of new beta-like cells in diabetic mice treated with EGF and CNTF

(A) Scheme of the experimental design for cell lineage tracing. (B) Rip ${ }^{\text {CreERT }}{ }^{2} 26^{\mathrm{LacZ}}$ mice were treated or not with ALX and implanted with pumps as indicated (see Figure 1 for details). At 7 days after pump implantation, the pancreas of each mouse was stained with XGal, with antibodies specific for PDX1 and amylase (AMY). DNA was stained with Hoechst 33342. (C) Quantification of labeled cells based on data shown in (B) (*: p<0.01; n=13). (D) Ela ${ }^{\text {CreERT }}$ R26 $6^{\mathrm{LacZ}}$ mice were treated or not with ALX and implanted with pumps as indicated (see Figure 1 for details). At 7 days after pump implantation, the pancreas of each mouse was stained with XGal, with anti-insulin (INS), anti-amylase (AMY) and Hoechst 33342. (E) Quantification of labeled cells based on data shown in (D) (*: p<0.01; $\mathrm{n}=13$ ). Overall Xgal labeling, representing the recombination efficiency, was $>80 \%$ in Rip $^{\text {CreERT }}$ 26 ${ }^{\mathrm{LacZ}}$ mice and $45 \%$ in Ela ${ }^{\mathrm{CreERT}} \mathrm{R} 26^{\mathrm{LacZ}}$ mice. 

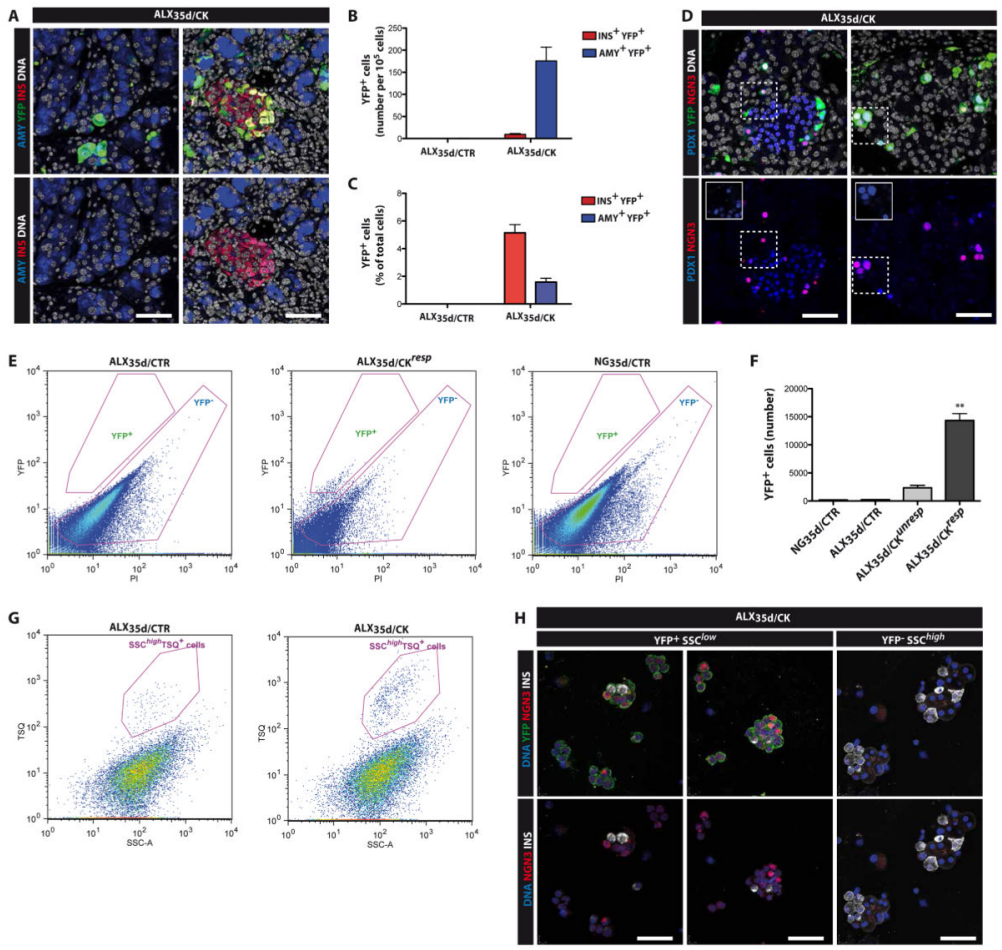

Figure 3. Re-activation of Ngn3 expression in the pancreas of $\mathrm{ALX}$ 35D/CK mice (A) Representative co-staining of pancreas sections of $\mathrm{ALX}_{35 \mathrm{~d} / \mathrm{CK}} \mathrm{Ngn} 3{ }^{\mathrm{YFP}}$ mice with antibodies specific for YFP, the acinar marker amylase (AMY) and the beta cell marker insulin (INS). DNA was visualized using Hoechst33342 (B-C) Quantification of labeled cells based on data shown in (A). (D) The pancreas of $\mathrm{ALX}_{35 \mathrm{~d} / \mathrm{CK}} \mathrm{Ngn} 3 \mathrm{YFP}^{\mathrm{YFP}}$ mice was stained with antibodies specific for YFP, Ngn3 and Pdx1 (insets clarify overlapping staining). (E) Pancreas of Ngn3 ${ }^{\mathrm{YFP}}$ knock-add-on mice ${ }^{27}$ was dissociated into single cells, and $\mathrm{YFP}^{+}$cells were analyzed by flow cytometry. Propidium iodide (PI) staining allowed exclusion of dead cells from the analysis. (F) Quantification of the cells isolated according to the parameters described in (E). (G) Beta cells were identified among the $\mathrm{YFP}^{-}$cells from $\mathrm{Ngn} 3^{\mathrm{YFP}}$ mice shown in $(\mathbf{E})$ as granulated $\left(\mathrm{TSQ}^{+} \mathrm{SSC}^{\text {high }}\right)$ cells. The beta cells represented $0.18 \pm 0.06 \%$ of pancreas cells in $\mathrm{ALX}_{35 \mathrm{~d} / \mathrm{CTR}}$ mice and $1.9 \pm 0.4 \%$ in $\mathrm{ALX}_{35 \mathrm{~d} / \mathrm{CK}}$ mice. (H) Sorted $\mathrm{YFP}^{+} \mathrm{SSC}^{\text {low }} \mathrm{TSQ}^{-}$and $\mathrm{YFP}^{-} \mathrm{SSC}^{\text {high }} \mathrm{TSQ}^{+}$cells were stained with antibodies specific for YFP, insulin and Ngn3. DNA was visualized using Hoechst33342. 


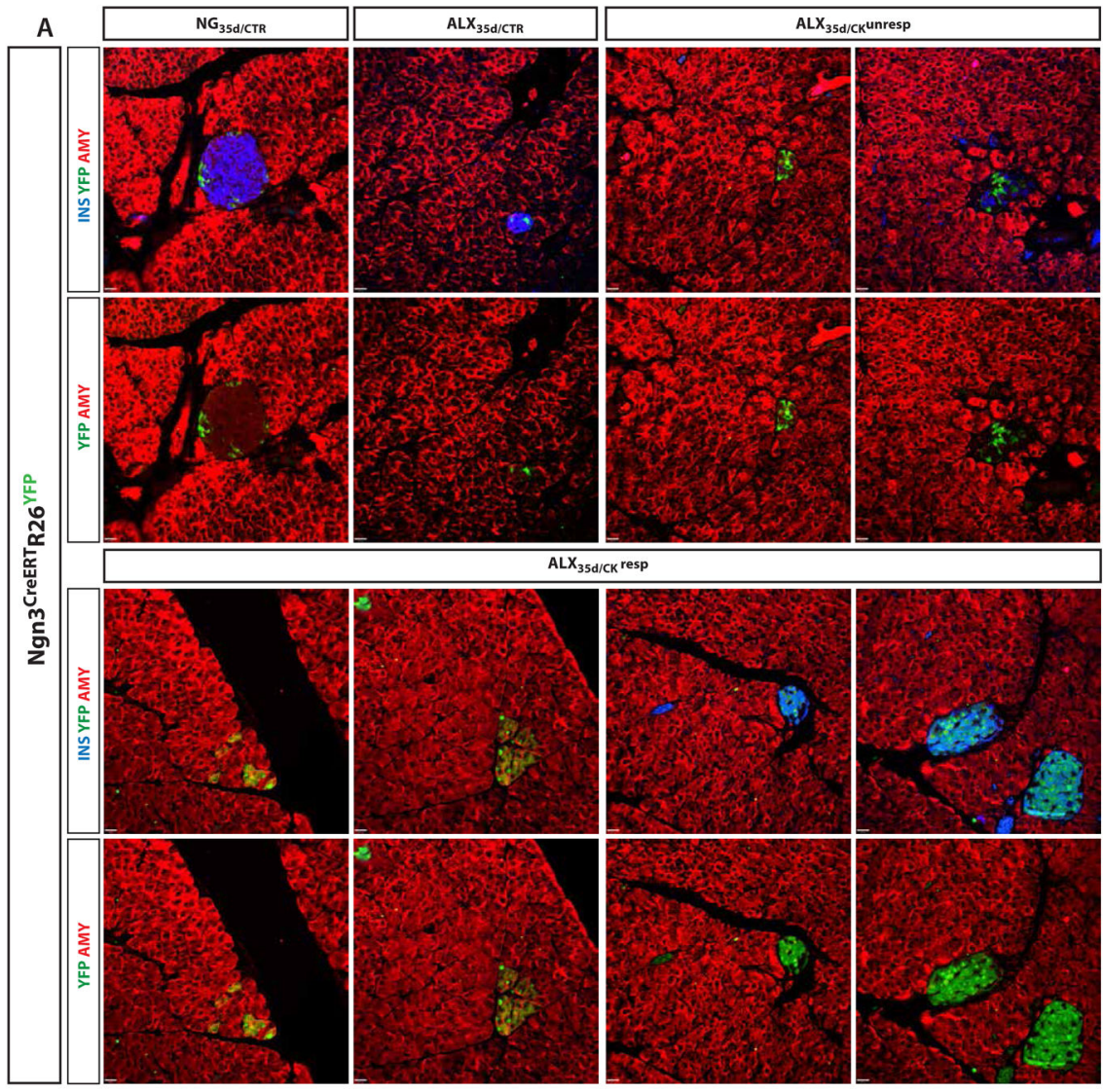

B

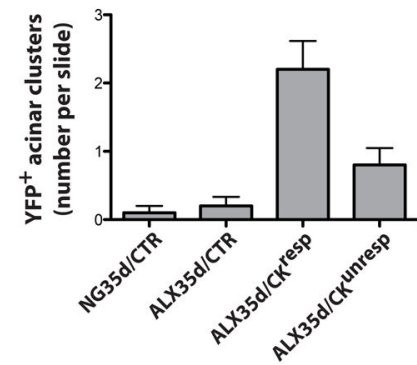

Figure 4. NGN3 expression during generation of new beta-like cells

(A,C) In Ngn3 ${ }^{\text {CreERT }}$ R26 ${ }^{\text {YFP }}$ tracer mice, cells that expressed Ngn3 at any time during

TAM-treatment are permanently marked by YFP expression. 33 days after ALX treatment,

TAM was injected at days $-2,0,2,4$ and 6 , with day 0 the day of pump implantation. At day 7 after pump implantation, the pancreases were stained with antibodies specific for amylase (AMY), insulin (INS) and YFP. (B) Numbers of clusters of three or more amylase ${ }^{+}$ insulin ${ }^{-}$acinar cells that were $\mathrm{YFP}^{+}$per single cross-section of the pancreas of $\mathrm{Ngn} 3{ }^{\mathrm{CreERT}} \mathrm{R} 26^{\mathrm{YFP}}$ mice that were treated as indicated (10 mice for each condition, 8 sections per mouse). (C) On the same section as in (B) the fraction of insulin ${ }^{+}$cells that expressed YFP was quantified. 


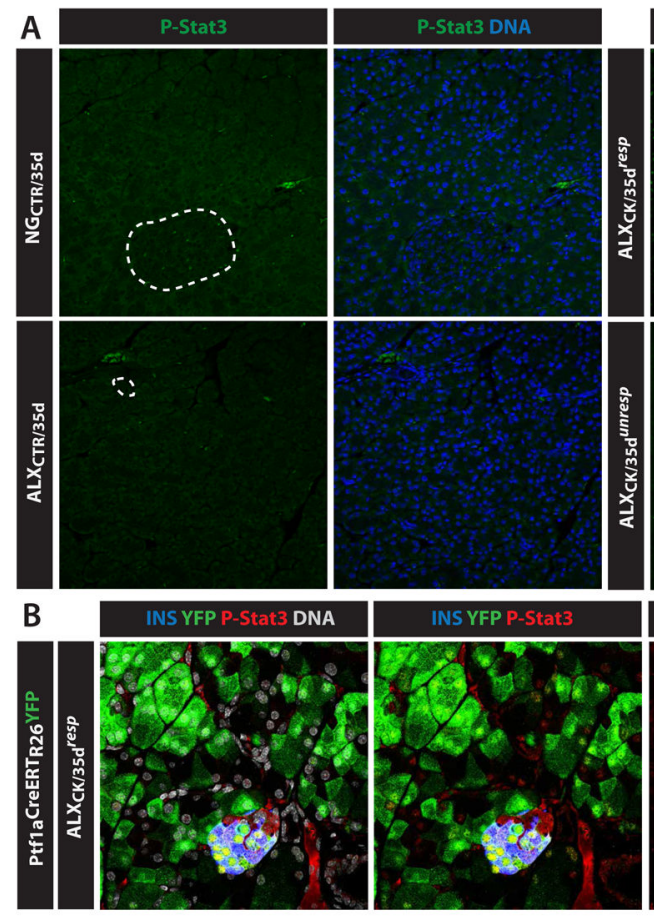

C

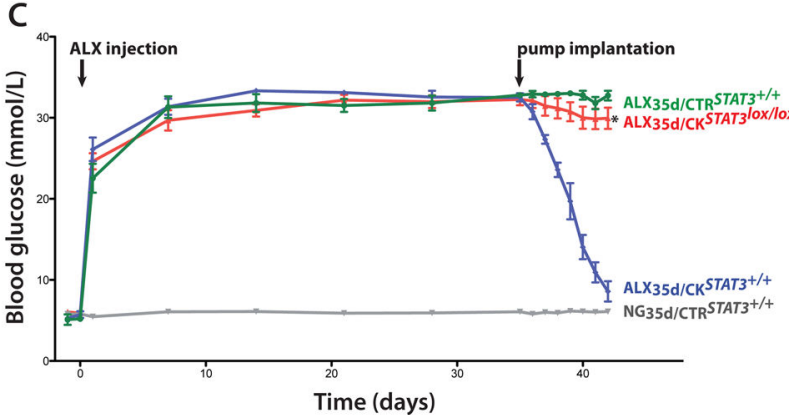

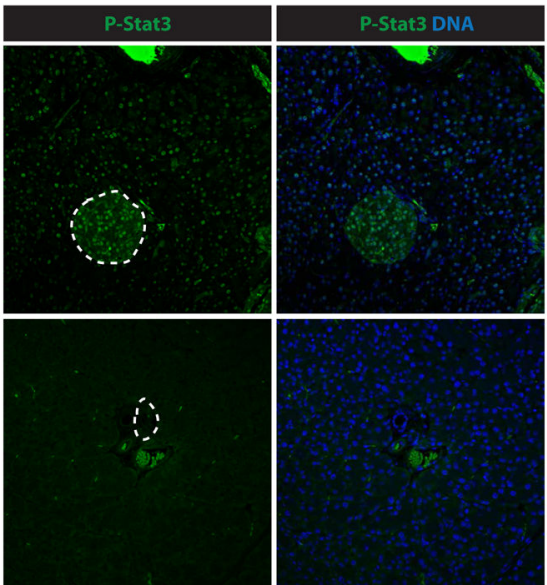

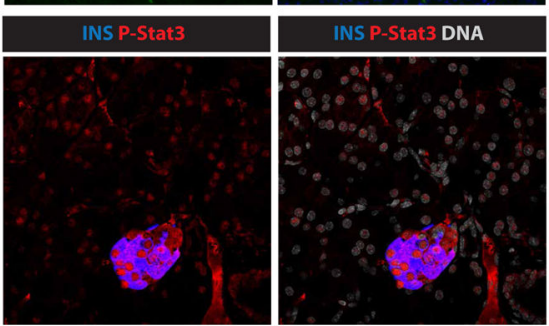

D

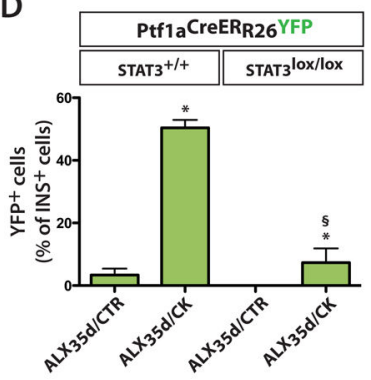

Figure 5. Stat3 in responsiveness to EGF and CNTF and restoration of normoglycemia

(A) STAT3 phosphorylation in pancreases of non-transgenic, hyperglycemic mice treated as indicated in Figure 2 was analyzed by immunohistochemistry. Dotted circles delineate islets of Langerhans. (B) STAT3 phosphorylation in pancreases of ALX $35 \mathrm{~d} / \mathrm{CK}{ }^{\text {resp }}$

Ptf1a ${ }^{\text {CreERT }}$ 26 ${ }^{\text {YFP }}$ lineage tracer mice to detect phosphorylated Stat3 in original acinar $\left(\mathrm{YFP}^{+}\right)$as well as newly formed beta-like cells $\left(\mathrm{YFP}^{+}\right.$insulin $\left.^{+}\right)$. (C) To selectively delete the Stat3 gene in pre-existing acinar cells, Ptf $1 \mathrm{a}^{\mathrm{CreERT}}{ }_{\mathrm{R} 26} 6^{\mathrm{YFP}} \mathrm{Stat} 3{ }^{\text {lox}} / \mathrm{lox}$ mice were treated with TAM before ALX injection. Where indicated, Ptf $1 \mathrm{a}^{\mathrm{CreERT}} \mathrm{R} 26^{\mathrm{YFP}} \mathrm{Stat} 3^{+/+}$mice were used as a control. Mice were then treated with pumps as in Figure 2A, and blood glucose was measured for the indicated time period. Following pump implantation, the glycemia was significantly higher in Stat $3^{\text {lox/lox }}$ mice compared to Stat $3^{+/+} \mathrm{ALX}_{35 \mathrm{~d} / \mathrm{CK}}$ mice $(8.6 \pm 1.2$ $\mathrm{mmol} / \mathrm{L} ; \mathrm{n}=4 ; \mathrm{p}<0.01$ ). (D) At day 7 after pump implantation, the fraction of insulin ${ }^{+}$cells expressing YFP was quantified on sections of pancreas of mice described in $(\mathbf{C}) .(*$ : $p<0.01$,

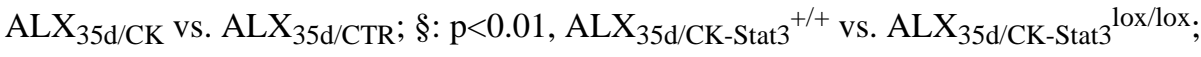
$\mathrm{n}=10$ ). 